\title{
Pricing of in-patent pharmaceuticals in the Middle East and North Africa: Is external reference pricing implemented optimally?
}

\author{
Panos Kanavos $^{\mathrm{a}, *}$, Bregtje W. Kamphuis ${ }^{\mathrm{a}}$, Anna-Maria Fontrier ${ }^{\mathrm{a}}$, Georgia Colville Parkin ${ }^{\mathrm{a}}$, \\ Shadi Saleh $^{\mathrm{b}}$, Kasem S. Akhras ${ }^{\mathrm{c}}$ \\ a Department of Health Policy, Medical Technology Research Group - LSE Health, London School of Economics and Political Science, Houghton Street, \\ London WC2A 2AE, United Kingdom \\ ${ }^{\mathrm{b}}$ Faculty of Health Sciences, American University of Beirut, Beirut, Lebanon \\ c Government Affairs E Market Access, MEA Region, AstraZeneca FZ LLC, $2^{\text {nd }}$ Floor Block D Building 27, Dubai Healthcare City, P.O. Box 5505070, Dubai, \\ United Arab Emirates
}

\section{A R T I C L E I N F O}

\section{Article history:}

Received 5 January 2020

Received in revised form 29 July 2020

Accepted 31 July 2020

\section{Keywords:}

External Reference Pricing

pharmaceutical policy

Middle East and North Africa

price regulation

cost containment

resource allocation

\begin{abstract}
A B S T R A C T
In this paper we outline and compare pharmaceutical pricing policies for in-patent prescription pharmaceuticals with emphasis on external reference pricing (ERP) in eleven countries across the Middle East and North Africa (MENA) region and explore possible improvements in their pricing systems. Primary and secondary evidence was used to inform our analysis. Comparative analysis of ERP systems across countries followed an analytical framework distilling ERP into twelve salient features, while ERP system performance was benchmarked against a framework of best practice principles across (a) objectives and scope, (b) administration and operations, (c) methods used, and (d) implementation. Results suggest that ERP is the dominant pricing method for in-patent pharmaceuticals. Although several good practice cases were identified, none of the eleven countries satisfy all best practice principles. ERP basket sizes vary significantly and are commonly composed using geographical proximity and low-price countries as criteria. Nine countries do not use the mean or median prices, but resort to using the lowest. Exchange rate fluctuations are routinely used to arrive at price reductions in local currency. Significant opportunities exist for MENA countries to develop their ERP regimes to achieve greater compliance with best practice principles. Over the short-term, incremental changes could be implemented to several ERP salient features and can be achieved relatively easily, thereby enhancing the functionality and performance of national ERP systems. Countries in the region can also focus on the development of explicit value assessment systems, and minimize their dependence on ERP over the longer-term.
\end{abstract}

(c) 2020 The Author(s). Published by Elsevier B.V. This is an open access article under the CC BY-NC-ND license (http://creativecommons.org/licenses/by-nc-nd/4.0/).

\section{Background}

The Middle East and North Africa (MENA) region stretches from Morocco to Oman and includes countries with diverse economic status and fragmented health care systems. The health care environment in the region is subject to considerable change and epidemiological (rising prevalence of non-communicable disease) as well as economic and fiscal pressure (rising health care costs and coverage issues). Total health expenditure ranges between $3.1 \%$ and $7.4 \%$ of GDP ( $\$ 435$ to $\$ 3,900$ per capita in purchasing power

\footnotetext{
* Corresponding author.

E-mail addresses: P.G.Kanavos@lse.ac.uk (P. Kanavos),B.W.Kamphuis@lse.ac.uk (B.W. Kamphuis), A.Fontrier@Ise.ac.uk (A.-M. Fontrier), G.Colville@lse.ac.uk (G. Colville Parkin), ss117@aub.edu.lb(S. Saleh), Kasem.Akhras@astrazeneca.com (K.S. Akhras).
}

parity (PPP) terms) (World Bank, 2019), but government health expenditure ranges between $1.25 \%$ and $4.98 \%$ of GDP (Fig. 1). Outof-pocket spending, captured by the difference between total and government health spending, remains significant. Pharmaceutical spending ranges between $11 \%$ and $49 \%$ of total health expenditure across the region (Fig. 1). Health care systems are fragmented, with many actors involved in the purchasing of prescription medicines, delivery of health care and reimbursement mechanisms (Kaló, et al., 2015; Qarain et al., 2009; Business Monitor International (BMI), 2017a, 2017b, 2017c, 2017d, 2017e, 2017f, 2017g).

Within this challenging context, pharmaceutical policy is increasingly subject to scrutiny, with a focus explicitly on controlling pharmaceutical costs given its substantial contribution to overall health expenditure. External reference pricing (ERP), the practice of one country using the list price of a pharmaceutical product in one or more countries to arrive at a reference price for 


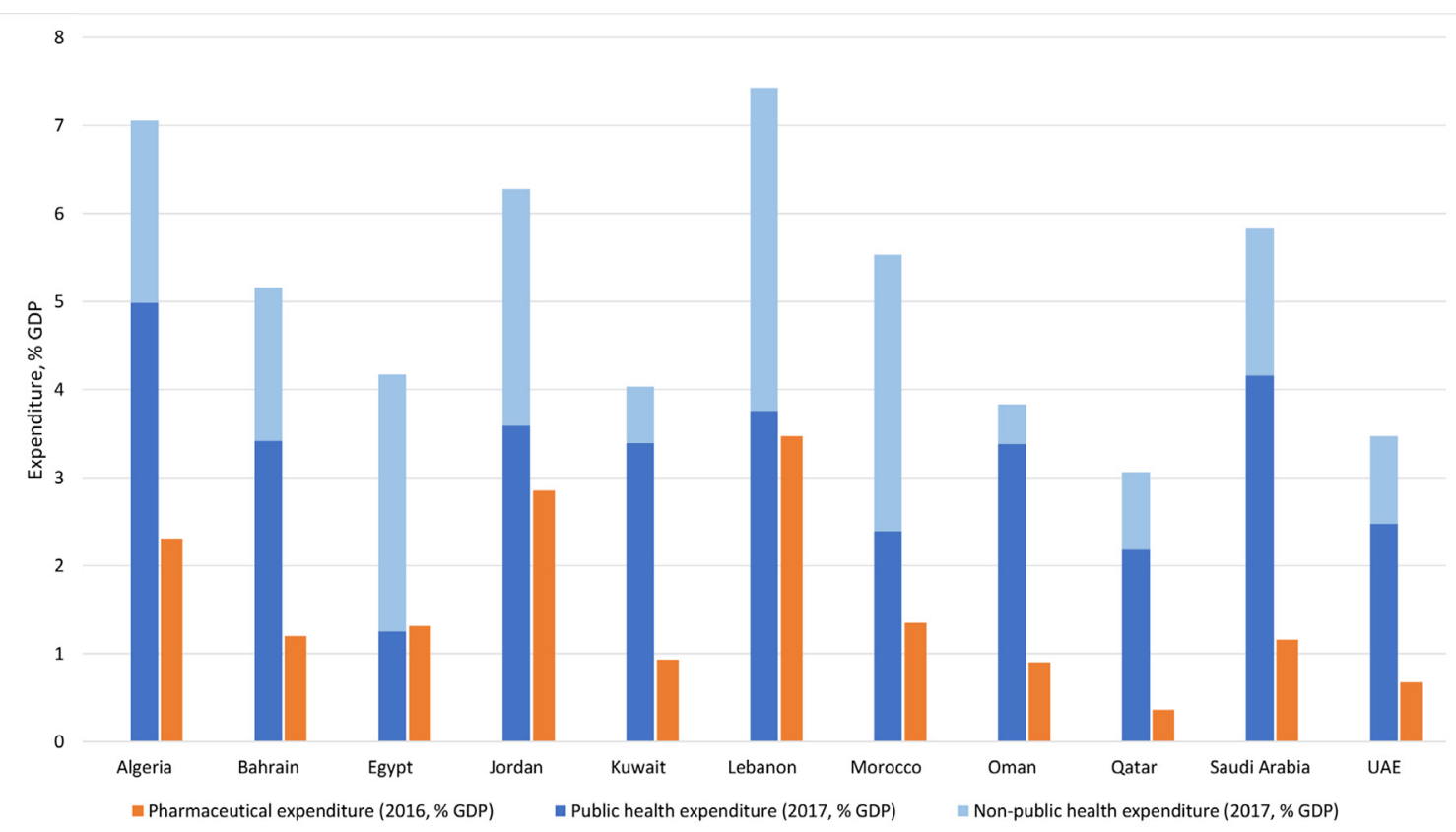

Fig. 1. Health care (total and public ${ }^{1}$ ) and pharmaceutical (total ${ }^{2}$ ) expenditure in MENA countries.

Sources: (World Bank, 2019; Business Monitor International (BMI), 2017a, 2017b, 2017c, 2017d, 2017e, 2017f, 2017j, 2017k, 2017l, Hammad, 2016; Kanavos et al., 2018).

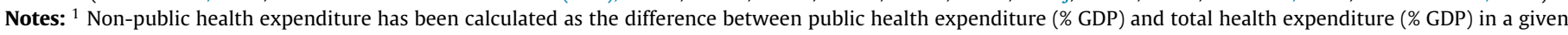
country.

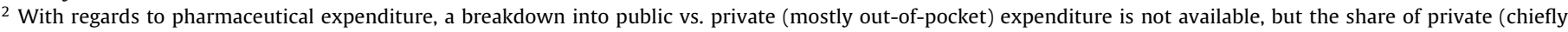

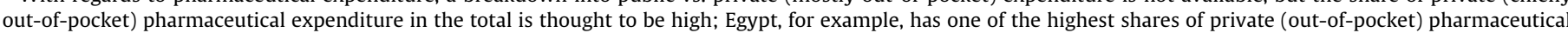
spending, relative to total pharmaceutical spending, at 70\% (Kanavos et al., 2018).

setting or negotiating the product price in its territory, is now the most commonly used pricing policy across the region for in- and off-patent pharmaceuticals.

Experimental studies on the impact of ERP on price levels and pharmaceutical savings are very limited, for a number of reasons including difficulties in isolating the impact of ERP from that of other policies or practices. Available evidence on the performance or comparative assessment of ERP systems in the region is limited. In general, ERP is straightforward, particularly for resource-limited countries. However, unavailable price information or issues with obtaining transaction prices necessary to implement ERP increase complexity (World Health Organization, 2015). As a result of using ERP, countries striving for lower prices may experience availability issues or access delays for certain prescription pharmaceuticals (Kaló et al., 2015; Espin et al., 2011; Gill et al., 2019; Kanavos et al., 2010; Leopold et al., 2012; Fontrier et al., 2019; Kanavos et al., 2020). This is due to launch sequencing or launch delays initiated by manufacturers, strategically launching in countries where higher prices can be achieved (Espin et al., 2011). ERP may lead to price reductions over time, and this depends on its design characteristics in each setting (Leopold et al., 2012; Håkonsen et al., 2009), though this finding may not hold in lower and middle-income countries (LMICs). Indeed, earlier work in the MENA region, concluded ERP may result in higher pharmaceutical prices in LMICs relative to prices for non-pharmaceutical services, although larger population size, reference baskets larger than five countries and the use of the lowest price in the basket significantly reduce relative pharmaceutical prices (Kaló, et al., 2015).

Considering the evidence gap in MENA ERP systems and their implementation, the objective of this paper is twofold: First, given the effects of ERP are often linked to design issues and implementation, we analyse the key features of ERP systems in the MENA region. Second, we critically appraise the performance of ERP systems in MENA countries across measures of their (i) objectives and scope, (ii) administration and operations, (iii) methods used and (iv) implementation based on an methodological framework that captures salient features of ERP (Sullivan et al., 2018).

\section{Analytical framework}

\subsection{Why regulate in-patent pharmaceuticals?}

Regulating in-patent pharmaceutical markets is a response to the imperfections of the market for pharmaceuticals comprising multiple stakeholders (payer-manufacturer-prescriberconsumer/patient) with different interests and objectives and the predictions of monopoly pricing or monopolistic behaviour by innovators. As monopolistic price-setting by the innovator may lead to poor market coverage, a regulator may either impose a price ceiling on new product prices or use an objective value assessment mechanism to inform price-setting and, through that, arrive at a maximum acceptable price. Where decision-makers struggle to set a suitable entry price below the monopoly price, do not have the capability to assess the value of new pharmaceutical products based on objective criteria and arrive at a price based on an ex ante determined willingness to pay (WTP) threshold or a price negotiation, they often resort to referencing prices from other settings iin an attempt to ensure that the resulting pharmaceutical prices in their territory are not excessive and contribute to macroeconomic efficiency.

\subsection{Salient features of ERP systems}

Based on evidence from primary and secondary sources (Gill et al., 2019; Fontrier et al., 2019; Kanavos et al., 2020) ERP can be decomposed into twelve key system features, as follows: (a) the role of ERP, defined by its use in informing pricing and/or reimbursement; (b) whether ERP occupies a main or supplementary role in pricing decisions (dominant pricing method vs. used in parallel with other criteria); (c) whether ERP occupies a main or 
supplementary role in reimbursement decisions; (d) the number of countries in the ERP basket; (e) the basket country selection criteria; (f) the price used to inform pricing decisions (average, median, lowest or other); (g) the information sources used in identifying and validating prices (publicly available vs. confidential); (h) the basis for reference price calculation (ex-factory, wholesale or retail); (i) whether ERP covers only in-patent, or also off-patent and generic pharmaceuticals; (j) whether pharmaceutical patent expiry in reference countries and concomitant price reductions, are used as means to initiate further price reductions in referent countries; (k) the exchange rate used to translate prices from foreign to local currency and how exchange rate volatility is dealt with; and (l) the frequency of price revisions (e.g. at launch only, annual, more frequent).

\subsection{Performance assessment of ERP systems}

Depending on a country's objectives and goals, ERP systems are designed to contain costs and encourage low prices. To evaluate the systems in the MENA region, an assessment of the alignment of national ERP systems to best practices in the design, introduction and implementation of ERP was performed using an analytical framework comprising good practice principles from the literature (World Health Organization, 2015; Gill et al., 2019; Kanavos et al., 2010; Fontrier et al., 2019; Kanavos et al., 2020; Sullivan et al., 2018).

Best practice principles expand on the salient features of ERP systems to include other factors pertaining to administration of and stakeholder participation in the system, covering issues relating four key areas of policy, notably, (i) objectives and scope, (ii) administration and operations, (iii) methods used, and (iv) implementation. As part of the objectives and scope, principles include (a) the design of a system in line with health system objectives, (b) the focus on in-patent pharmaceuticals, and (c) the likelihood of introducing an explicit value assessment system in the future. For administration and operations, we consider whether systems (a) are administratively simple and transparent, (b) allow stakeholders to participate in its design and review, and (c) have established a straightforward process and opportunities for stakeholder appeals. ERP methods should satisfy a number of criteria: (a) select ERP reference countries based on similarities in economic status and health system objectives, ((b) take international implications of ERP into consideration, (c) methods to perform calculations should be based on publicly available ex-factory prices, (d) the mean or median price of the basket should be selected, (e) price information should be based on available information and employ methods to reduce exchange rate volatility, and (f) referencing prices of off-patent pharmaceuticals within reference countries where onpatent pharmaceuticals have lost their patent status should be avoided. Implementation of ERP should (a) note that price revisions should happen on a scheduled, but infrequent, basis, with a publicly available revision schedule and (b) consider that when ERP is used to set prices alongside other methods of value determination, the system should consider the relative importance of ERP in determining prices and how ERP aligns with such tools. A summary of best practice principles is shown in Table 1.

\section{Methods}

The study relies on both primary and secondary data collection. In terms of secondary data, a systematic literature review was conducted in accordance with CRD guidelines (Center for Reviews and Dissemination, 2008) to identify a relevant bibliography on ERP in peer-reviewed and grey literature. Eleven MENA countries (Algeria, Bahrain, Egypt, Jordan, Kuwait, Lebanon, Morocco,
Table 1

Best practice principles of External Reference Pricing (ERP)

\begin{tabular}{|c|c|}
\hline No. & EPR best practice principle \\
\hline 1 & $\begin{array}{l}\text { The objectives of ERP systems should be clear and align with } \\
\text { health system objectives }\end{array}$ \\
\hline 2 & $\begin{array}{l}\text { ERP systems should focus on in-patent products considered for the } \\
\text { purposes of coverage, pricing and reimbursement decisions }\end{array}$ \\
\hline 3 & $\begin{array}{l}\text { Prices developed via ERP do not override HTA conclusions or VBP } \\
\text { approaches }\end{array}$ \\
\hline 4 & $\begin{array}{l}\text { The ERP system should have administrative simplicity and } \\
\text { transparency }\end{array}$ \\
\hline 5 & $\begin{array}{l}\text { Stakeholders should participate in design and review of ERP } \\
\text { system }\end{array}$ \\
\hline 6 & Stakeholders should be able to appeal regulator decisions \\
\hline 7 & $\begin{array}{l}\text { Reference countries should be selected based on similarities in } \\
\text { economic status and health system objectives }\end{array}$ \\
\hline 8 & $\begin{array}{l}\text { International implications of ERP implementation should be } \\
\text { considered }\end{array}$ \\
\hline 9 & $\begin{array}{l}\text { Publicly available ex-factory prices should form the basis of the } \\
\text { ERP system }\end{array}$ \\
\hline 10 & The mean of prices in reference countries should be used \\
\hline 11 & $\begin{array}{l}\text { ERP systems should respect the patent status of products it covers } \\
\text { based on intellectual property (IP) rights provisions that prevail in } \\
\text { referent country }\end{array}$ \\
\hline 12 & ERP formula should avoid the impact of exchange rate volatility \\
\hline 13 & $\begin{array}{l}\text { Price revisions should be kept to a minimum and should be carried } \\
\text { out consistently to avoid the perception of opportunistic behaviour }\end{array}$ \\
\hline 14 & $\begin{array}{l}\text { ERP-based prices should be aligned with other tools used when } \\
\text { negotiating reimbursement }\end{array}$ \\
\hline
\end{tabular}

Source: (Gill et al., 2019; Fontrier et al., 2019; Kanavos et al., 2020; Sullivan et al., 2018).

Table 2

Search strategy for the identification of literature on ERP in MENA countries.

"Price Regulation" OR “Pharmaceutical Regulation" OR “Regulation” OR "Price legislation" OR "Price legislations" OR "Price controls" OR "Price control" OR "Pharmaceutical Policy" OR "Policy" OR "Pricing" OR "External Reference Pricing" OR “External Price Referencing” OR "International Price Comparisons" OR "International Reference Pricing" OR “International Price Referencing" OR "Price Harmonization" OR "Price Unification" OR “Unified Pricing” OR "Reference Pricing” OR "Price Referencing"

AND

"Drug" OR "drugs" OR "medicine" OR "medicines" OR "pharmaceutical" OR "pharmaceuticals"

AND

"Middle East" OR "North Africa" OR "GCC" OR "Gulf Cooperation Council” OR "Algeria" OR "Egypt" OR "Morocco" OR "Lebanon" OR "Jordan" OR "Saudi Arabia" OR "Kuwait" OR "United Arab Emirates" OR "UAE" OR "Qatar" OR "Bahrain" OR "Oman"

Oman, Qatar, the Kingdom of Saudi Arabia (KSA), and the United Arab Emirates (UAE)) were selected for study given all belong to the same geographical area and use ERP to inform price-setting of in-patent pharmaceuticals (Kaló et al., 2015; Business Monitor International (BMI), 2017f, 2017h, 2017i; Abuelkhair et al., 2012; Hammad, 2016; Khan et al., 2015; Mohamed, 2014; Ministry of Health of the Sultanate of Oman and World Health Organization, 2011; Alrasheedy et al., 2017; Anonymous, 2018). We used (a) the endpoints included in the analytical framework to perform a mapping of ERP systems in the study countries and (b) the performance assessment endpoints based on the best practice principles to arrive at an assessment of their performance on a comparative basis.

ProQuest, Web of Science, Medline, EconLit and CINAHL were searched using keywords, including synonyms and different phrasings of "ERP and pharmaceuticals" and study country names (Table 2). The search was limited to English articles published between 1 January 2000 and 31 May 2020. The search was restricted to keywords presented within document titles only, to limit the number of irrelevant papers. All documents were downloaded and imported to EndNote and duplicate references were removed. The 
articles were initially screened by two of the authors (BK and GC) for relevance by title and abstract. Papers with relevant titles and/or abstracts were downloaded for further examination of the main text for relevance against the selected endpoints. Publications providing information on at least one of the endpoints were included, and using an excel spreadsheet, two of the authors (BK and GC) extracted the relevant information against each endpoint. A targeted search of official documents from Health Ministries and regulatory authority websites in the countries of interest, the World Health Organization (WHO), the World Bank and other grey literature sources, including market sources, were also reviewed to identify further information on the endpoints. Additionally, a targeted Google search was performed, the results of which were imported in the same spreadsheet, where the relevant text was extracted and sorted against the study endpoints.

Primary data was collected through a survey (May - September 2018) to validate secondary data findings and obtain a practical view of the current operating environment in the study countries. Over 80 experts and stakeholders were contacted via email, including government officials, industry executives, and expertes from regulatory authorities, insurance organizations, pharmacy departments and procurement agencies. Survey questions were designed according to the salient features and performance indicators identified, and related to: (a) details of pricing policies and price setting; (b) key features of the ERP system in each country; and (c) evidence of ERP impact within and across countries, notably on affordability, availability, barriers, and regional or international implications. Responses were subsequently coded thematically to extract key concepts and trends throughout the region. In addition to completing the survey, all respondents were invited to interview guided by semi-structured interview guides, covering aspects of ERP features and performance, with content tailored to gather information on the gaps, barriers and bottlenecks identified per country and further detail on practical issues resulting from ERP. A final round of triangulation took place during a face-to-face meeting in Dubai in September 2018 between the lead author (PK) and decision-makers from the study countries aiming to validate the original findings with experts from study country competent authorities.

In order to present our findings on ERP systems in eleven countries, we report our findings on the design and implementation of these systems along the framework developed on salient features of ERP, and subsequently assess the performance of these systems against the best practice principles outlined in Table 1. Where clear evidence of adherence to a principle was identified, country performance was scored positively, and where evidence of non-adherence to each principle was identified, performance was scored as either not or only partially fulfilling the principle. This analysis was followed by results on the performance of each country in line with the ERP best practice principles.

\section{Results}

\subsection{Available evidence on ERP in MENA}

Of 368 identified studies, 28 were included and reviewed (Fig. 2), including peer-reviewed literature $(n=6)$, grey literature $(n=20)$ and legislative documents $(n=2)$. Sources covered countries either individually or as a region and provided information on the salient features of ERP or its implementation. One or more sources were found for most countries, except Algeria where no relevant literature was identified.

Through the survey and follow-up interviews, ten experts contributed material and insights on the salient features of ERP systems and practical implementation issues. No primary data was obtained for Oman, but evidence was obtained through direct contact with the country's governmental sources of the Ministry of Health (MoH).

\subsection{Salient features of ERP regimes for in-patent pharmaceuticals in the MENA region}

Table 3 highlights the key features of ERP systems across the region. ERP occupies a main role in pricing of in-patent, off-patent, imported generic and biosimilar pharmaceuticals in Algeria and may be used as a guide for reimbursement (Business Monitor International (BMI), 2017c; Anonymous, 2018). The Algerian ERP basket comprises nine countries, including the product's countryof-origin (COO) (Business Monitor International (BMI), 2017c; Holtorf et al., 2019). Countries are selected based on geographical proximity, comparable GDP levels, the product's COO, socioeconomic factors, such as universal healthcare systems, and countries with affordable European prices (Anonymous, 2018). The ERP system relies on ex-factory and retail prices in the reference countries with information obtained from manufacturers and public sources (Anonymous, 2018; Holtorf et al., 2019). The reference price is the lowest basket price and is revised every five years (except for locally manufactured pharmaceuticals), or in response to price changes in basket countries (Anonymous, 2018; Holtorf et al., 2019). Price adjustments are possible in response to exchange rate fluctuations by using the current exchange rate (Anonymous, 2018; Holtorf et al., 2019).

In Bahrain, ERP is used for the pricing of in-patent pharmaceuticals; it may be used for pricing of generics, together with other tools such as internal reference pricing (IRP) or price capping (Anonymous, 2018). In-patent pharmaceutical prices are set considering the price in the COO, ex-factory prices, cost, insurance and freight (CIF) prices in the Gulf Cooperation Council (GCC) region, the therapeutic significance of the drug, drug prices found in official pricing references, prices of similar drugs in Bahrain and, if available, pharmacoeconomic studies (Al Abbasi and Al Jalahma, 2017; Anonymous, 2018; Holtorf et al., 2019). The reference basket comprises at least six countries, which are selected based on geographical proximity and COO (Al Abbasi and Al Jalahma, 2017; Anonymous, 2018) and the reference price is the lowest in the basket (Holtorf et al., 2019). Price revisions can take place during the registration period of a drug (typically 5 years) and during registration renewal (Al Abbasi and Al Jalahma, 2017; Holtorf et al., 2019). During the registration period, price revisions are performed if: (a) there is a price reduction for the product in the COO; or (b) the product has been registered with a lower price in another GCC country; or (c) there is a change in the manufacturing site; or (d) at the manufacturer's request (Al Abbasi and Al Jalahma, 2017). Price adjustments are possible to account for currency fluctuations, although all CIF prices are set in USD to prevent such fluctuations (Al Abbasi and Al Jalahma, 2017; Anonymous, 2018).

The Egyptian ERP version relies on a basket of 36 countries (Kaló, et al., 2015; Qarain et al., 2009; Mohamed, 2014; Holtorf et al., 2019; Wanis, 2015). Country selection is based on geographical proximity, comparable GDP levels and the COO, and relies on retail prices obtained from manufacturers and public sources (Kaló, et al., 2015; Anonymous, 2018; Holtorf et al., 2019). The reference price is the lowest in the basket, and regulation suggests the price is revised every five years or in response to currency fluctuations (if these are $+/-15 \%$ in a year), or at manufacturers' request, limited to a maximum of $5 \%$ of their product portfolio per year (Kaló, et al., 2015; Mohamed, 2014; Anonymous, 2018; Holtorf et al., 2019; Wanis, 2015). No price adjustments are allowed to compensate for inflation but can occur in light of exchange rate fluctuations (Qarain et al., 2009; Business Monitor International (BMI), 2017a; Mohamed, 2014; Holtorf et al., 2019; Wanis, 2015). 
Table 3

Salient features of ERP in the MENA region.

\begin{tabular}{|c|c|c|c|c|c|c|c|c|c|c|c|c|}
\hline & \multicolumn{5}{|c|}{ Role of ERP } & \multicolumn{3}{|l|}{ Basket of countries } & \multirow{2}{*}{$\begin{array}{l}\text { Price type } \\
\text { used }\end{array}$} & \multirow{2}{*}{$\begin{array}{l}\text { Information } \\
\text { sources for } \\
\text { pricing } \\
\text { decisions }\end{array}$} & \multirow{2}{*}{$\begin{array}{l}\text { Price } \\
\text { calculation }\end{array}$} & \multirow{2}{*}{$\begin{array}{l}\text { Price } \\
\text { revisions }\end{array}$} \\
\hline & $\begin{array}{l}\text { Use in } \\
\text { pricing }\end{array}$ & $\begin{array}{l}\text { Role in price } \\
\text { setting for } \\
\text { in-patent phar- } \\
\text { maceuticals }\end{array}$ & $\begin{array}{l}\text { Use for } \\
\text { pricing } \\
\text { off-patent } \\
\text { drugs }\end{array}$ & $\begin{array}{l}\text { Use for } \\
\text { pricing } \\
\text { generic } \\
\text { drugs }\end{array}$ & $\begin{array}{l}\text { Use for } \\
\text { in-patent } \\
\text { reimburse- } \\
\text { ment }\end{array}$ & $\begin{array}{l}\text { Number of } \\
\text { basket countries } \\
\text { (including COO } \\
\text { where used) }\end{array}$ & $\begin{array}{l}\text { Countries in the } \\
\text { basket }\end{array}$ & $\begin{array}{l}\text { Country } \\
\text { selection } \\
\text { criteria }\end{array}$ & & & & \\
\hline Algeriaa $^{1,2}$ & $\sqrt{ }$ & Main & $\sqrt{ }$ & $\sqrt{ }^{\dagger}$ & $\sqrt{ }^{-}$ & 9 & $\begin{array}{l}\text { BE, ES, FR, GR, } \\
\text { MA, TN, TR, UK + } \\
\text { COO }\end{array}$ & $\begin{array}{l}\text { Geographical } \\
\text { proximity; } \\
\text { Compara- } \\
\text { ble GDP } \\
\text { levels; } \\
\text { COO; } \\
\text { Socio- } \\
\text { economic } \\
\text { factors; } \\
\text { Affordable } \\
\text { European } \\
\text { prices }\end{array}$ & $\begin{array}{l}\text { Ex-factory } \\
\text { and retail } \\
\text { prices }\end{array}$ & $\begin{array}{l}\text { Manufacturer; } \\
\text { public } \\
\text { informa- } \\
\text { tion } \\
\text { sources }\end{array}$ & $\begin{array}{l}\text { Lowest } \\
\text { price }\end{array}$ & $\begin{array}{l}\text { Every } 5 \text { years; } \\
\text { price changes in } \\
\text { basket counties }\end{array}$ \\
\hline Bahrain $^{1,3}$ & $\sqrt{ }$ & Main & - & $\sqrt{ }$ & - & $>6$ & $\begin{array}{l}\text { KSA, KW, OM, } \\
\text { QA, UAE + COO } \\
\text { May include } \\
\text { other countries } \\
\text { not specified in } \\
\text { pricing guideline }\end{array}$ & $\begin{array}{l}\text { Geographical } \\
\text { proximity; } \\
\text { COO }\end{array}$ & $\begin{array}{l}\text { Ex-factory } \\
\text { and CIF } \\
\text { prices }\end{array}$ & - & $\begin{array}{l}\text { Lowest } \\
\text { price }\end{array}$ & $\begin{array}{l}\text { During } 5 \text { year } \\
\text { registration } \\
\text { period under } \\
\text { defined } \\
\text { circumstances }\end{array}$ \\
\hline Egypt $^{4}$ & $\sqrt{ }$ & Main & $x$ & $x$ & $x$ & 36 & $\begin{array}{l}\text { AR, AT, BE, BH, } \\
\text { CA, CH, CY, DE, } \\
\text { DK, DZ, ES, FI, } \\
\text { FR, GR, HU, IE, } \\
\text { IN, IR, IT, JO, JP, } \\
\text { KSA, KW, LB, } \\
\text { MA, NL, NO, OM, } \\
\text { PH, PL, PT, SD, } \\
\text { SE, TR UAE, UK }\end{array}$ & $\begin{array}{l}\text { Geographical } \\
\text { proximity; } \\
\text { Compara- } \\
\text { ble GDP } \\
\text { levels; COO }\end{array}$ & $\begin{array}{l}\text { Retail } \\
\text { prices }\end{array}$ & $\begin{array}{l}\text { Manufacturer; } \\
\text { public } \\
\text { informa- } \\
\text { tion } \\
\text { sources }\end{array}$ & $\begin{array}{l}\text { Lowest } \\
\text { price }\end{array}$ & $\begin{array}{l}\text { Every } 5 \text { years; } \\
\text { currency } \\
\text { exchange } \\
\text { fluctuations; } \\
\text { manufacturer's } \\
\text { request }\end{array}$ \\
\hline Jordan $^{1,5,6,7,13}$ & $\sqrt{ }$ & Main & $\sqrt{ }$ & $\sqrt{ }^{\dagger}$ & - & 18 & $\begin{array}{l}\text { AT, AU, BE, CY, } \\
\text { CZ, ES, FR, GR, } \\
\text { HR, HU, IE, IT, } \\
\text { NL, NZ, PT, UK + } \\
\text { COO / KSA as an } \\
\text { option for the } \\
\text { lowest price }\end{array}$ & Unclear & $\begin{array}{l}\text { Retail and } \\
\text { ex-factory } \\
\text { prices }\end{array}$ & $\begin{array}{l}\text { Manufacturer; } \\
\text { public } \\
\text { informa- } \\
\text { tion } \\
\text { sources }\end{array}$ & $\begin{array}{l}\text { Median } \\
\text { price }\end{array}$ & $\begin{array}{l}\text { Every } 2 \text { years } \\
\text { after initial reg- } \\
\text { istration; } \text {;every } 5 \\
\text { years thereafter; } \\
\text { changes in } \\
\text { currency } \\
\text { exchange rates; } \\
\text { price reductions } \\
\text { in KSA }\end{array}$ \\
\hline Kuwait $^{8}$ & $\sqrt{ }$ & Main & $x$ & $x$ & $\sqrt{ }$ & 5 & $\begin{array}{l}\text { BH, KSA, OM, } \\
\text { QA, UAE }\end{array}$ & $\begin{array}{l}\text { Socio- } \\
\text { economic } \\
\text { factors; } \\
\text { geographi- } \\
\text { cal }\end{array}$ & $\begin{array}{l}\text { CIF price } \\
\text { and retail } \\
\text { prices }\end{array}$ & $\begin{array}{l}\text { Manufacturer; } \\
\text { public } \\
\text { informa- } \\
\text { tion } \\
\text { sources }\end{array}$ & $\begin{array}{l}\text { Lowest } \\
\text { price }\end{array}$ & $\begin{array}{l}\text { Price changes in } \\
\text { basket countries } \\
\text { or in a GCC } \\
\text { country }\end{array}$ \\
\hline
\end{tabular}


Table 3 (Continued)

\begin{tabular}{|c|c|c|c|c|c|c|c|c|c|c|c|}
\hline \multicolumn{5}{|c|}{ Role of ERP } & \multicolumn{3}{|c|}{ Basket of countries } & \multirow{2}{*}{$\begin{array}{l}\text { Price type } \\
\text { used }\end{array}$} & \multirow{2}{*}{$\begin{array}{l}\text { Information } \\
\text { sources for } \\
\text { pricing } \\
\text { decisions }\end{array}$} & \multirow{2}{*}{$\begin{array}{l}\text { Price } \\
\text { calculation }\end{array}$} & \multirow{2}{*}{$\begin{array}{l}\text { Price } \\
\text { revisions }\end{array}$} \\
\hline $\begin{array}{l}\text { Use in } \\
\text { pricing }\end{array}$ & $\begin{array}{l}\text { Role in price } \\
\text { setting for } \\
\text { in-patent phar- } \\
\text { maceuticals }\end{array}$ & $\begin{array}{l}\text { Use for } \\
\text { pricing } \\
\text { off-patent } \\
\text { drugs }\end{array}$ & $\begin{array}{l}\text { Use for } \\
\text { pricing } \\
\text { generic } \\
\text { drugs }\end{array}$ & $\begin{array}{l}\text { Use for } \\
\text { in-patent } \\
\text { reimburse- } \\
\text { ment }\end{array}$ & $\begin{array}{l}\text { Number of } \\
\text { basket countries } \\
\text { (including COO } \\
\text { where used) }\end{array}$ & $\begin{array}{l}\text { Countries in the } \\
\text { basket }\end{array}$ & $\begin{array}{l}\text { Country } \\
\text { selection } \\
\text { criteria }\end{array}$ & & & & \\
\hline$\sqrt{ }$ & Main & $\sqrt{ }$ & $x$ & $x$ & 15 & $\begin{array}{l}\text { BE, BH, CH, ES, } \\
\text { FR, IT, JO, KSA, } \\
\text { KW, OM, PT, QA, }\end{array}$ & Unclear & $\begin{array}{l}\text { CIF, } \\
\text { wholesaler } \\
\text { and retail }\end{array}$ & Manufacturer & $\begin{array}{l}\text { Lowest } \\
\text { price }\end{array}$ & $\begin{array}{l}\text { Every } 5 \text { years; } \\
\text { price changes in } \\
\text { basket countries }\end{array}$ \\
\hline
\end{tabular}

Morocco $^{1,9,10} \quad \sqrt{ } \quad$ Main

$\operatorname{Oman}^{1,6,12,15} \quad \sqrt{ } \quad$ Main

Qatar $^{1}$

Main

Saudi Arabia ${ }^{11} \quad \checkmark \quad$ Main
KW, OM, PT, QA

BE, ES, FR, KSA,

Geographical prices

PT, TR + COO

proximity:

Ex-fact
prices

$\mathrm{COO}$

(n)

BH, KSA, KW,

QA, UAE + COO

plus countries

with official

references for

prices; prices of

drugs in the

same

pharmacological

group

$\mathrm{BH}, \mathrm{KW}, \mathrm{OM}$,

Geographical

$\mathrm{UAE}+\mathrm{COO}$

proximity

CIF and

retail prices

Manufacturer; Lowest

$\mathrm{AR}, \mathrm{AU}, \mathrm{BE}, \mathrm{BH}$,

$\mathrm{CA}, \mathrm{CH}, \mathrm{CY}, \mathrm{DE}$,

DK, DZ, EG, ES,

FR, GR, HU, IE, IT,

LB, NL, NZ, OM,

LB, NL, NZ, OM,
PT, SE, TR, UAE,

UK

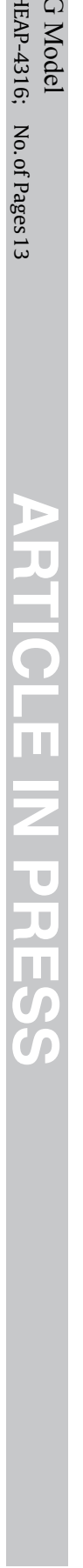


Table 3 (Continued)

\begin{tabular}{|c|c|c|c|c|c|c|c|c|c|c|c|c|}
\hline & \multicolumn{5}{|c|}{ Role of ERP } & \multicolumn{3}{|l|}{ Basket of countries } & \multirow{2}{*}{$\begin{array}{l}\text { Price type } \\
\text { used }\end{array}$} & \multirow{2}{*}{$\begin{array}{l}\text { Information } \\
\text { sources for } \\
\text { pricing } \\
\text { decisions }\end{array}$} & \multirow{2}{*}{$\begin{array}{l}\text { Price } \\
\text { calculation }\end{array}$} & \multirow{2}{*}{$\begin{array}{l}\text { Price } \\
\text { revisions }\end{array}$} \\
\hline & $\begin{array}{l}\text { Use in } \\
\text { pricing }\end{array}$ & $\begin{array}{l}\text { Role in price } \\
\text { setting for } \\
\text { in-patent phar- } \\
\text { maceuticals }\end{array}$ & $\begin{array}{l}\text { Use for } \\
\text { pricing } \\
\text { off-patent } \\
\text { drugs }\end{array}$ & $\begin{array}{l}\text { Use for } \\
\text { pricing } \\
\text { generic } \\
\text { drugs }\end{array}$ & $\begin{array}{l}\text { Use for } \\
\text { in-patent } \\
\text { reimburse- } \\
\text { ment }\end{array}$ & $\begin{array}{l}\text { Number of } \\
\text { basket countries } \\
\text { (including COO } \\
\text { where used) }\end{array}$ & $\begin{array}{l}\text { Countries in the } \\
\text { basket }\end{array}$ & $\begin{array}{l}\text { Country } \\
\text { selection } \\
\text { criteria }\end{array}$ & & & & \\
\hline $\mathbf{U A E}^{14}$ & $\sqrt{ }$ & Main & $x$ & $\sqrt{ }^{\dagger}$ & $x$ & 18 & $\begin{array}{l}\text { AT, BE, BH, CA, } \\
\text { CH, DE, DK, ES, } \\
\text { FI, FR, IE, IT, KSA, } \\
\text { KW, NL, NO, SE, } \\
\text { UK }\end{array}$ & $\begin{array}{l}\text { Geographical } \\
\text { proximity; } \\
\text { COO }\end{array}$ & $\begin{array}{l}\text { Ex-factory, } \\
\text { import } \\
\text { price, CIF } \\
\text { prices }\end{array}$ & $\begin{array}{l}\text { Manufacturer; } \\
\text { public } \\
\text { informa- } \\
\text { tion } \\
\text { sources }\end{array}$ & $\begin{array}{l}\text { Median } \\
\text { price }\end{array}$ & $\begin{array}{l}\text { Periodic } \\
\text { reviews: every } 5 \\
\text { years; prices } \\
\text { change in basket } \\
\text { countries } \\
\text { Exceptional } \\
\text { reviews in } \\
\text { defined } \\
\text { circumstances }\end{array}$ \\
\hline
\end{tabular}

1 Figure for number of basket countries includes $\mathrm{COO}$.

2 Price-cut is mandatory if BE, ES, FR or UK, is the lowest price in the basket (30).

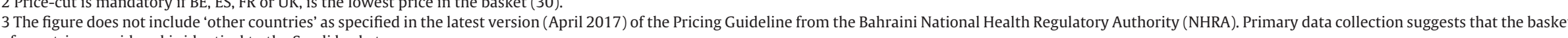
of countries considered is identical to the Saudi basket.

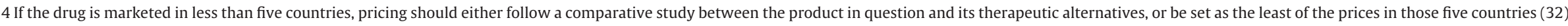
5 If the product is not priced in all countries, the median price is taken in no less than four countries, as available $(30,33)$.

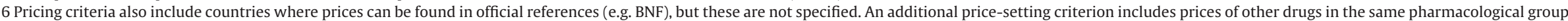

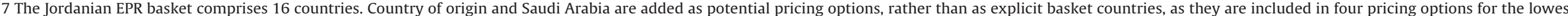
price (Price in COO, in KSA, across basket, or export price).

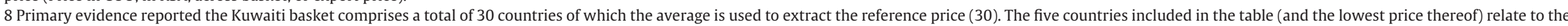
GCC basket, which is used routinely in price setting.

9 The $\mathrm{COO}$ is included in the basket when the price is different and when the price is equal to ex-factory price of $\mathrm{COO}$ if not launched in the basket countries (30).

10 The average price of the basket is considered for existing products, contrary to the lowest price which is considered for new pharmaceuticals (30).

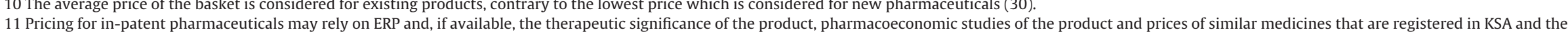
11 Pricing for in-patent pharmaceuticals may rely on ERP a

12 Pricing for in-patent pharmaceuticals also relies on IRP.

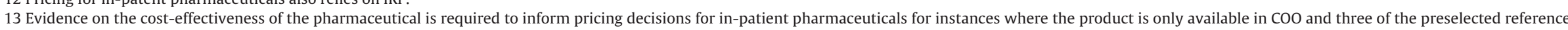
countries.

14 ERP use for pricing of generics is restricted to imported or partially locally manufactured generics, and does not apply to wholly locally manufactured products.

15 ERP use for the pricing of generics is for prices in the Omani private sector.

Key: $\sqrt{ }=$ yes / used

$x=$ no $/$ not used.

$\sqrt{ }-=$ Used as a reference price/guide and/or not necessarily in a systematic way.

$\sqrt{ } \dagger=$ used solely for imported generics and/or biosimilars.

$\sqrt{ }^{*}=$ used solely for locally manufactured generics and/or biosimilars.

$\checkmark \neq=$ used solely when the originator is not present in the home market.

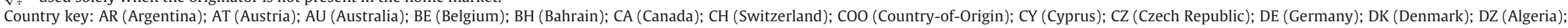

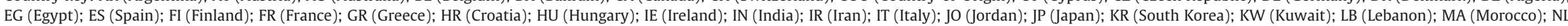

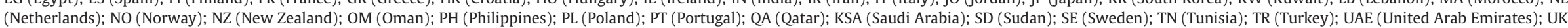
(United Kingdom).

Source: Adapted by the authors from the findings of both primary and secondary data collection presented in the results section. 


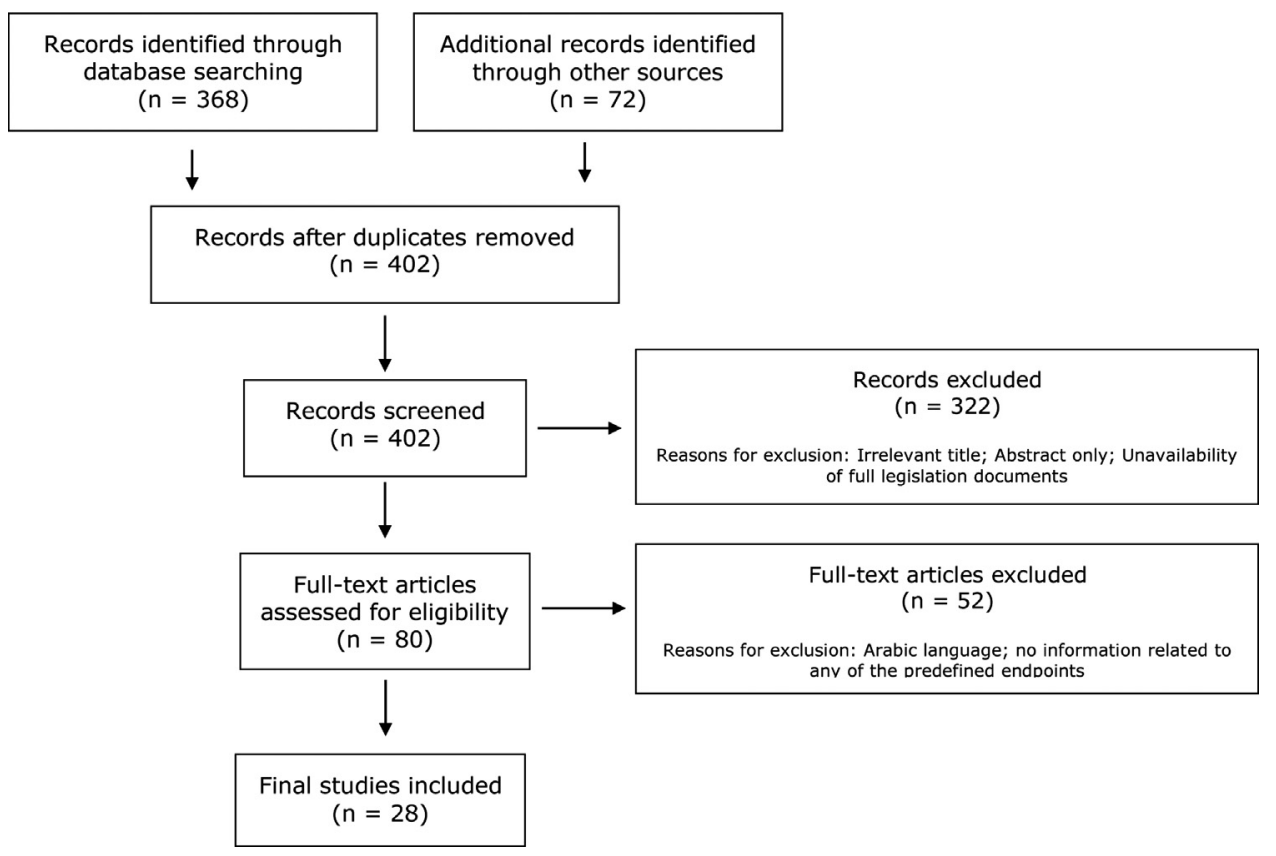

Fig. 2. PRISMA flowchart for Systematic Literature Review of ERP in the MENA region.

ERP plays a main role in price setting of in- and off-patent pharmaceuticals and imported generics in Jordan, where the Jordan Drug and Food Administration (JFDA) selects the lowest price out of (a) the price in the $\mathrm{COO}$, (b) the price in KSA and (c) the median price of a basket of 16 countries) (Kaló et al., 2015; Qarain et al., 2009; Hammad, 2016; Anonymous, 2018; El-Dahiyat and Curley, 2017). The complete reference basket, therefore, is made up of a total of 18 countries (Kaló et al., 2015; Qarain et al., 2009; Business Monitor International (BMI), 2017g; Espin et al., 2011; Hammad, 2016; Holtorf et al., 2019; El-Dahiyat and Curley, 2017). No specific criteria are used to select basket countries (Anonymous, 2018). Retail and ex-factory prices supplied by manufacturers and found in publicly available sources are used to inform price setting (Kaló et al., 2015; Espin et al., 2011; Holtorf et al., 2019; El-Dahiyat and Curley, 2017). Price revisions occur as follows: (a) two years after initial registration and every five years thereafter (Kaló et al., 2015; Qarain et al., 2009; Anonymous, 2018; El-Dahiyat and Curley, 2017); (b) if changes in currency exchange rates take place in the reference basket including the $\mathrm{COO}$; or (c) if a price reduction takes place in KSA (Business Monitor International (BMI), 2017b; Anonymous, 2018; Kanavos et al., 2018). Price adjustments due to exchange rate fluctuations take place quarterly (Anonymous, 2018; Holtorf et al., 2019).

ERP is used as a main price setting policy in Kuwait, where the basket comprises five countries (Anonymous, 2018), all from the GCC, although pricing guidance may be based on a larger basket of 30 countries. Basket countries are selected based on socioeconomic and geographical criteria. Price data is based on CIF and retail prices provided by manufacturers and available in the public domain (Kaló, et al., 2015; Anonymous, 2018; Holtorf et al., 2019). Reference prices are the lowest in the basket and may be revised due to price changes in key basket countries or one of the GCC countries (Kaló et al., 2015; Anonymous, 2018; Holtorf et al., 2019). A fixed exchange rate based on the average over the past six months, is used by the $\mathrm{MoH}$ to address potential exchange rate fluctuations (Anonymous, 2018).

ERP plays a main role in price setting in Lebanon for in- and offpatent pharmaceuticals, where the basket comprises 15 countries (Business Monitor International (BMI), 2017d; Holtorf et al., 2019;
Abdel Rida et al., 2019). No specific criteria are used to select basket countries (Anonymous, 2018). Prices are based on CIF, wholesaler and retail prices in basket countries as provided by the manufacturer (Kaló et al., 2015; Espin et al., 2011; Anonymous, 2018; Holtorf et al., 2019). The reference price is the lowest in the basket and can be revised every five years or when prices change in key basket countries (Kaló, et al., 2015; Anonymous, 2018; Holtorf et al., 2019). Price adjustments are possible to account for exchange rate fluctuations every fifteen days (Business Monitor International (BMI), 2017d; Anonymous, 2018; Holtorf et al., 2019; Ammar, 2009).

ERP plays a pivotal role in Morocco's pricing strategy of in\& off-patent pharmaceuticals and generic pharmaceuticals when the originator product is not present in the Moroccan market (Anonymous, 2018); reference prices are used as a guide for reimbursement. The basket references seven countries including the COO (Business Monitor International (BMI), 2017i). Geographical proximity and the $\mathrm{COO}$ are the main criteria for basket country selection (Anonymous, 2018). ERP uses ex-factory prices in basket countries obtained from manufacturers and publicly available sources. The reference price is the lowest in the basket and can be revised every five years. Price revisions occur on a number of occasions, including (a) the loss of market exclusivity by the originator, (b) exchange rate fluctuation by more than $10 \%$, (c) when there is a change in the pharmaceutical formula or packaging, (d) on the basis of the result of annual benchmarking in the reference countries, or (e) when prices change in the basket countries (Anonymous, 2018).

ERP is used as a main tool for price setting for both in-patent, off-patent and generic pharmaceuticals in Oman, though prices can also be set based on prices in the same therapeutic group and prices in official reference tools, such as the British National Formulary (Ministry of Health of the Sultanate of Oman and World Health Organization, 2011). The ERP basket consists of at least six countries, with the reference price being the lowest (Espin et al., 2011; Ministry of Health of the Sultanate of Oman and World Health Organization, 2011; Holtorf et al., 2019). The ERP system is based on ex-factory, CIF, wholesale, and retail prices provided by manufacturers (Business Monitor International (BMI), 2017e). Prices are revised every 5 years or on GCC harmonization (Holtorf et al., 2019). 
In Qatar ERP is the key tool informing in- and off-patent pharmaceutical pricing decisions and is used as a guide for reimbursement (Anonymous, 2018; Abdel Rida et al., 2019). The Qatari basket is small, referencing five countries including the COO (Anonymous, 2018). Basket countries are identified through geographical proximity to Qatar (Anonymous, 2018). CIF and retail prices are obtained through manufacturers and access to GCC CIF prices (Kaló et al., 2015; Anonymous, 2018; Holtorf et al., 2019). The reference price is the lowest in the basket and prices are revised when changes in key basket countries occur (Kaló et al., 2015; Business Monitor International (BMI), 2017f; Holtorf et al., 2019). All CIF prices are set in USD to prevent currency fluctuations (Anonymous, 2018).

ERP is the key tool informing price-setting for pharmaceuticals in KSA and may be used in reimbursement. The following information informs pricing decisions: (i) ex-factory and wholesale price in $\mathrm{COO}$; (ii) retail prices in $\mathrm{COO}$ and other countries where the product is marketed; (iv) CIF price to KSA in the COO currency; (v) CIF prices to countries in which the product is marketed; and, if available: (vi) the price in official pricing sources; (vii) product therapeutic significance; (viii) relevant pharmacoeconomic studies; (ix) prices of similar medicines that are registered in KSA; and (x) the proposed price by the manufacturer (Kaló et al., 2015; Qarain et al., 2009; Khan et al., 2015; Business Monitor International (BMI), 2017h; Alrasheedy, et al., 2017; Hajed, 2020). The KSA basket comprises 30 countries (Kaló, et al., 2015; Qarain et al., 2009; Khan et al., 2015; Business Monitor International (BMI), 2017h; Alrasheedy, et al., 2017; Holtorf et al., 2019; Hajed, 2020) and the ERP price is the lowest in the basket (Kaló, et al., 2015; Khan et al., 2015; Holtorf et al., 2019). Price revisions take place every five years at product registration renewal (Khan et al., 2015).

In the UAE, ERP is used for price setting of imported in-patent pharmaceuticals and generics, except for pricing of wholly locally manufactured generics. Price sources include official websites and prices submitted by manufacturers. There are 18 countries in the UAE basket, largely composed of European and neighbouring countries to the UAE (Qarain et al., 2009; Espin et al., 2011; Abuelkhair, et al., 2012; United Arab Emirates Ministry of Health and Prevention, 2018). Ex-factory, import, and CIF prices are collected from basket countries (Kaló, et al., 2015; Qarain et al., 2009; Espin et al., 2011; Holtorf et al., 2019; United Arab Emirates Ministry of Health and Prevention, 2018) and the reference price is the basket median (Kaló, et al., 2015; United Arab Emirates Ministry of Health and Prevention, 2018). Two types of price revisions occur in the UAE (United Arab Emirates Ministry of Health and Prevention, 2018): periodic reviews occur every five years along with renewal of product registration, under which all innovative product prices are revised; exceptional price revisions are triggered due to patent expiry, product changes, or upon request of national health authorities. In the UAE, there are price adjustments to mitigate exchange rate fluctuations (Anonymous, 2018; Business Monitor International (BMI), 2017j).

Overall, in-patent pharmaceutical list prices across the study countries are set based on ERP (for both the retail and in-patient markets), yet interesting nuances exist at country level, including the prices in $\mathrm{COO}$ and the GCC and the use of IRP as co-determinants in price-setting (Kaló, et al., 2015; Qarain et al., 2009; ; Espin et al., 2011; Abuelkhair, et al., 2012; Khan et al., 2015; Ministry of Health of the Sultanate of Oman and World Health Organization, 2011; Business Monitor International (BMI), 2017f, Business Monitor International (BMI), 2017h; Alrasheedy, et al., 2017; Al Abbasi and Al Jalahma, 2017). With regards to reimbursement, ERP-derived list prices are reimbursed in the case of retail products, whereas in-patient products are covered based on tenders.

ERP is, thus, often combined with price assessments in the COO (Bahrain, Jordan, Lebanon, Oman, and KSA), or with IRP to derive the product prices in the same therapeutic class (Bahrain, Oman, and Jordan for pharmaceuticals only available in the COO). Several countries are now considering the therapeutic significance of new pharmaceuticals (Bahrain and KSA) and (may) require pharmacoeconomic studies during price-setting (Bahrain, Egypt, Jordan and KSA). While the inclusion of pharmacoeconomic studies has been documented in the literature, their consideration in practice is still unclear, perhaps with the exception of Egypt, where they are used frequently to inform pricing and, mainly, coverage decisions.

\subsection{Alignment with the principles for best practice in ERP}

We applied the 14 best practice principles to the study countries in order to determine each country's degree of alignment with these principles covering the objectives and scope of ERP systems, administration and operations, methods used, and ERP implementation (see Table 4). Overall, none of the eleven countries satisfy all 14 principles, with most failing to implement an administratively simple and transparent system or to use mean basket prices. Most countries have large baskets and use the lowest basket price, reducing administrative simplicity. Because ERP is often designed as an administratively driven process, many of its forms in the MENA region exclude active stakeholder participation. Many of the countries in the region revise prices if their exchange rate fluctuates or if prices change in basket countries in order to capitalise on the possibility of further price diminution.

With few exceptions, it appears that the key objective of ERP across MENA countries is to satisfy cost containment objectives by benchmarking against the lowest list prices from inherently diverse and large ERP baskets. The question, of course, is whether this objective can be satisfied. List prices, that form the basis of ERP calculation, for most new products are no longer representative of net or transaction prices as reference countries routinely resort to risk-sharing agreements (RSAs), confidential discounting and negotiations to ensure the cost of new products is affordable to them (Kanavos et al., 2020). This necessitates relevant systems of value assessment, risk sharing and negotiation to be in place, all of which are currently missing from the MENA region.

While value assessment systems still remain aspirational across the MENA region there are trends towards the adoption of HTA either explicitly or implicitly, such as the recent policy on universal health coverage in Egypt (Ministry of Planning Monitoring and Administrative Reform (Egypt), 2016) and KSA's Vision 2030 (Kingdom of Saudi Arabia, 2020). Meanwhile, the impact of ERP can be distorting as artificial benchmarks are created and there is no meaningful notion of local value assessment of new products and their implications or importance in the countries in which they are introduced. Consequently, ERP on its own, may not be the optimum pricing policy for achieving competitive, appropriate and affordable price levels, compared to a more dynamic pricing policy, which allows an expression of value in their national context.

The decision-making community's awareness of and response to international implications of ERP differs between MENA countries. In some cases, there is awareness of international implications, but these are not taken into consideration (e.g. the UAE, Egypt, Morocco, and Jordan) (Anonymous, 2018). In other cases, decision-makers are aware of the international implications of ERP and attempt to mitigate them, (e.g. Algeria, where attempts are in place to designing a legal mechanism to determine two prices, a list price and a confidential transaction price) (Anonymous, 2018). 
Table 4

External Price Referencing in MENA countries: Adherence to best practice principles.

\begin{tabular}{|c|c|c|c|c|c|c|c|c|c|c|c|c|c|c|c|}
\hline & $\begin{array}{l}\text { GDP per } \\
\text { capita, } \\
2018 \\
\text { adjusted } \\
\text { for PPP\$ }\end{array}$ & $\begin{array}{l}\text { Clear } \\
\text { objectives } \\
\text { aligning } \\
\text { with policy } \\
\text { goals }\end{array}$ & $\begin{array}{l}\text { Focus on } \\
\text { in-patent } \\
\text { drugs only }\end{array}$ & $\begin{array}{l}\text { EPR prices } \\
\text { do not } \\
\text { override } \\
\text { HTA } \\
\text { decisions }\end{array}$ & $\begin{array}{l}\text { Admini- } \\
\text { stratively } \\
\text { simple and } \\
\text { transparent }\end{array}$ & $\begin{array}{l}\text { Stakeholder } \\
\text { participa- } \\
\text { tion }\end{array}$ & $\begin{array}{l}\text { Possibility } \\
\text { to appeal }\end{array}$ & $\begin{array}{l}\text { Appropriate } \\
\text { country } \\
\text { selection }\end{array}$ & $\begin{array}{l}\text { Consideration of } \\
\text { international } \\
\text { implications }\end{array}$ & $\begin{array}{l}\text { Use of } \\
\text { ex-factory } \\
\text { prices }\end{array}$ & $\begin{array}{l}\text { Use of } \\
\text { mean } \\
\text { prices }\end{array}$ & $\begin{array}{l}\text { Respect of } \\
\text { patent } \\
\text { status }\end{array}$ & $\begin{array}{l}\text { Avoid } \\
\text { impact of } \\
\text { exchange } \\
\text { rate }\end{array}$ & $\begin{array}{l}\text { Price } \\
\text { revisions to } \\
\text { a minimum }\end{array}$ & $\begin{array}{l}\text { Alignment } \\
\text { with } \\
\text { negotiation } \\
\text { tools }\end{array}$ \\
\hline Algeria & 15,622 & $\sqrt{ }$ & $x$ & $\mathrm{~N} / \mathrm{A}$ & $x$ & $x$ & $x^{1}$ & $x^{1}$ & $x^{1,2}$ & $\sqrt{ }$ & $x$ & $x^{1}$ & $x$ & $x$ & $x$ \\
\hline Bahrain & 47,212 & $x$ & $\sqrt{ }$ & $\mathrm{N} / \mathrm{A}$ & $\sqrt{ }$ & $x$ & $\sqrt{ }$ & $\sqrt{ }$ & $x$ & $\sqrt{ }$ & $x$ & $\sqrt{ }$ & $x^{1}$ & $x$ & $x$ \\
\hline Egypt & 12,390 & $x$ & $x$ & $\mathrm{~N} / \mathrm{A}$ & $x$ & $x^{1}$ & $x^{1}$ & $x$ & $x$ & $x$ & $x$ & $x^{1}$ & $x^{1}$ & $x$ & $\sqrt{ }$ \\
\hline Jordan & 9,348 & $\sqrt{ }$ & $\sqrt{ } \sim$ & $\mathrm{N} / \mathrm{A}$ & $\sqrt{ }$ & $\sqrt{ } \sim$ & $\sqrt{ }$ & $x$ & $x$ & $\sqrt{ }$ & $\sqrt{ }^{3}$ & $x$ & $\sqrt{ }$ & $x$ & $x$ \\
\hline Kuwait & 73,705 & $x$ & - & $\mathrm{N} / \mathrm{A}$ & $\sqrt{ }$ & $\sqrt{ }$ & $\sqrt{ }$ & $x$ & $x$ & $x$ & $x$ & - & $x$ & $x$ & $x$ \\
\hline Lebanon & 13,058 & $\sqrt{ }$ & $x$ & $\mathrm{~N} / \mathrm{A}$ & $\sqrt{ }$ & $x$ & $\sqrt{ }$ & $x$ & $x^{1,2}$ & $x$ & $x$ & $\sqrt{ }$ & $\checkmark$ & $x$ & $x$ \\
\hline Morocco & 8,587 & $\sqrt{ }$ & $x$ & $\mathrm{~N} / \mathrm{A}$ & $\sqrt{ }$ & $\sqrt{ }$ & $\sqrt{ }$ & $\sqrt{ }$ & $x$ & $\sqrt{ }$ & $x$ & $\sqrt{ }$ & $\sqrt{ }$ & $x$ & $\sqrt{ }$ \\
\hline Oman & 41,435 & - & $x$ & $\mathrm{~N} / \mathrm{A}$ & $\sqrt{ }$ & - & - & $x^{1}$ & - & $\sqrt{ }$ & $x$ & - & - & $x$ & $x$ \\
\hline Qatar & 126,598 & $x$ & $\sqrt{ }$ & $\mathrm{N} / \mathrm{A}$ & $\sqrt{ }$ & $x$ & $\sqrt{ }$ & $\sqrt{ }$ & $x$ & $x$ & $x$ & $\sqrt{ }$ & $\sqrt{ }$ & $x$ & $x$ \\
\hline Saudi Arabia & 55,120 & $x$ & $\sqrt{ }$ & $\mathrm{N} / \mathrm{A}$ & $x$ & $x$ & $\sqrt{ }$ & $x$ & $x$ & $\sqrt{ }$ & $x$ & $\sqrt{ }$ & $\sqrt{ }$ & $\sqrt{ }$ & $x$ \\
\hline UAE & 74,943 & $x$ & $\sqrt{ } \sim$ & $\mathrm{N} / \mathrm{A}$ & $\sqrt{ }$ & $x$ & $\sqrt{ }$ & $\sqrt{ }$ & $x$ & $\sqrt{ }$ & $\sqrt{3}^{3}$ & $\sqrt{ }$ & $\sqrt{ }$ & $\sqrt{ }$ & $x$ \\
\hline
\end{tabular}

Notes: ${ }^{1}$ Primary and secondary data collection and triangulation with multiple sources suggest this criterion is not met.

${ }^{2}$ While it has been mentioned that local decision-makers consider the international implications, it is unclear how this is applied in practice.

Median price.

Key: ' $\sqrt{ }$ ' = satisfies.

' $x$ ' = does not satisfy.

$' \sqrt{ } \sim$ ' = partially satisfies.

Source: GDP per capita: (1); all other: LSE interpretation based on primary and secondary data collection and further triangulation with stakeholders. 


\section{Discussion}

Our analysis of MENA country ERP systems presents a number of lessons for policy. First, across the region, ERP informs pricing decisions, which, in turn, inform coverage and reimbursement. Mechanisms, such as negotiation processes and innovative contracting, particularly through the use of risk sharing, aiming to assess value whilst mitigating the high cost of new medicines, are absent.

Second, although there is no formal value assessment or explicit HTA system in operation in any of the MENA countries, three of the countries undertake ad hoc economic evaluations of some inpatent pharmaceuticals. Although this is done in an unsystematic manner, there are trends towards these assessments, such as the recently passed legislation on universal health insurance coverage in Egypt and KSA's Vision 2030, where mention of HTA and broader efficiency criteria are made.

Third, ERP systems may depend on the list prices for many new products from MENA reference basket countries, which may not be reflective of net prices (Gill et al., 2019; Kanavos et al., 2020). In addition, the type of comparator prices used to inform the pricing of pharmaceuticals in ERP include combinations of ex-factory, wholesale, retail or CIF prices. All countries besides Egypt, Kuwait, Lebanon, and Qatar employ ex-factory prices in their ERP systems. In Algeria, Egypt, Jordan, Lebanon, Morocco, Oman, Qatar, and the UAE, the responsibility for providing information for pricing decisions to the competent authority rests with pharmaceutical manufacturers (Espin et al., 2011; Anonymous, 2018). In Qatar, confidential pricing information on GCC CIF prices is also used (Anonymous, 2018). None of the study countries use mean prices; Jordan and the UAE use median prices and Morocco uses the average only for existing products and selects the lowest price for newly launched products, while all other countries use the lowest price in their respective basket.

Fourth, the patterns identified indicate that the higher the country's income per capita, the greater its adherence to best practice principles. Despite this observation, the pursuit of administrative simplicity, appropriate country selection (based on comparable income levels or levels of economic development), and use of mean prices remain an elusive target in the region, with few exceptions. The findings from primary research suggest that administrative processes are complex and resource-intensive in much of the region (particularly in Algeria, Egypt, and KSA), in part resulting from the intensity of information required because of large basket sizes and re-pricing frequencies. Additionally, very often, low- or middleincome countries are included in reference baskets, which results in prices declining continuously (Kanavos et al., 2018).

Fifth, few countries have made improvements to their ERP systems in recent years; notable exceptions are the UAE and KSA which have implemented provisions in line with several best practice principles, such as respecting patent status, focusing on in-patent drugs, avoiding the use of exchange rate volatility as a means of price reduction, minimising price revision frequencies, enable appeals, and using ex-factory prices.

From a health care system perspective, an ERP system does not necessarily reflect the benefit arising from innovative therapies. This is due to the design characteristics of ERP: first, while the reference baskets in many of the study countries include countries that use HTA mechanisms to inform price-setting, the use of the lowest price, effectively negates the input from these countries to be used. Second, patent expiries in reference countries and concomitant price reductions in these may relate to patent status of a particular product and the differences in the expiry of patent terms across settings. It is possible for patents to expire first in several reference countries with prices declining due to generic competition or the imposition of administrative measures (e.g. mandatory price decrease); referent countries may want to capitalise on that despite the product still being under patent in their markets. Third, although price adjustments can be implemented to account for exchange rate fluctuations, countries tend not to account for dynamic exchange rate changes or reference country wealth differences, especially if countries with stronger currencies or higher incomes per capita are used as reference. Often, exchange rates used are unrealistic and can offer a significant discount to newly launched products upon entry, resulting in launch delays or product shortages for products that have already been launched (Kanavos et al., 2020). Only Jordan, Lebanon, Morocco, Qatar, KSA and the UAE use techniques such as accounting for exchange rate moving averages (Lebanon), or using a single currency to prevent currency fluctuations (Qatar, Jordan) (Anonymous, 2018; Ammar, 2009). Fourth, re-pricing should be selective in order to create a stable price environment that encourages the launch of new products. If ERP takes place biannually and the lowest in the basket is selected, a race towards the bottom is almost certainly the outcome. In principle, re-pricing in most study countries occurs every three to five years from a statutory perspective, leading to the least possible disruption or instability, unless prices change in basket countries or exchange rates fluctuate, in which case referrent countries are in a constant struggle to update list prices. Only KSA and UAE conform to the principle of 'infrequent re-pricing' in the strict sense, while, elsewhere, re-pricing can be triggered if prices change in key basket countries (Algeria, Bahrain, Jordan, Kuwait, Morocco, and Qatar), if exchange rates fluctuate (Morocco, Jordan), in response to packaging changes (Morocco), or in response to manufacturing site changes, and upon manufacturer requests (Bahrain) (Al Abbasi and Al Jalahma, 2017).

Although requesting the same price in lower income markets as in higher income markets could lead to in-patent pharmaceuticals becoming excessively expensive in low and middle income countries (LMICs), ERP per se does not definitively impact pharmaceutical affordability in LMICs unless combined with other tools that address this policy concern. If, as appears to be the case in most MENA countries, ERP results in a price that is reimbursed by the countries concerned without further action on reimbursement negotiation, then, unavoidably, questions arise about the extent to which list prices are affordable, particularly among some of the lower income countries in the region. Additionally, an inflexible pricing system which 'borrows' prices from other settings, without further elaboration or negotiation, may delay launches in those countries or even deter price approval, and consequently, market entry.

Given the nature of ERP, broader international implications, such as price convergence and spill-over effects due to launch delays, are to be expected. ERP policies adopted by MENA countries lead to new, in-patent pharmaceutical product price convergence between countries of different economic status (Kaló, et al., 2015). The GCC price harmonisation process is leading to downward price convergence as the process is designed to reduce pharmaceutical prices in the GCC and the broader MENA region (Business Monitor International (BMI), 2017g), with Egypt, Jordan and Algeria referencing GCC countries (Business Monitor International (BMI), 2017g). Evidence shows that ERP may delay new product launch because many new pharmaceutical products are not launched or remain unapproved until reference countries have determined their prices (Kaló, et al., 2015). The exception to this was the UAE, which used a fast track pricing process, whereby it would only reference the country of origin to improve launch of and access to priority drugs. 


\subsection{Limitations}

Our analysis is not without limitations. First, although the attributions made to the 14 best practice principles were based on evidence obtained from local $\mathrm{MoH}$ and expert surveys and interviews, they remain subjective, but are based on triangulation from all available sources. Second, the literature review relied on sources limited to the English language and relevant studies published in other languages, if they exist, unavoidably have been excluded; future research can address this gap. Finally, given pharmaceutical pricing policies are constantly changing and updated, the evidence presented in this study will not reflect the future policy landscape, but is a good benchmark at this point in time.

\section{Policy implications}

Two key policy implications arise from the analysis and with regards to pharmaceutical pricing and reimbursement in the MENA region: first, there is a need to reform ERP systems over the midto long-term in order for them to become more effective and efficient pricing tools as well as encourage and deliver affordable prices where these are needed; and, second, there is also a need to establish more formalised arrangements around clinical benefit and value assessment in order for these to be conducted locally and with a view to ultimately replacing ERP over the long-term.

Our analysis suggests that a number of improvements can be made to MENA ERP systems by prioritising certain design elements, which are more amenable to change in the short-run. These include: (a) improvements in basket country selection, both in terms of the number of countries in the basket and the country selection criteria; (b) improvements in price revision frequencies in many of the study countries; (c) use of publicly available ex-factory prices to obtain mean (or median) prices from the basket, while wealth adjustments based on differential GDP per capita between basket countries and referent country can be used if the former are significantly wealthier than the latter; and (d) use ERP for in-patent products only.

Beyond reforming the design elements raised above, MENA countries should also focus on longer-term reform aspects of their individual pricing systems; for example, they should recognise and account for the international implications of ERP; equally, they should not rely solely on ERP to inform pricing decisions, echoing trends seen elsewhere, where ERP is not the centrepiece in pharmaceutical pricing policy (Fontrier et al., 2019; Kanavos et al., 2020), but is used as a supplement to a range of other tools (e.g. HTA, risk sharing agreements (RSAs)) to arrive at affordable prices and provides the starting point for reimbursement negotiations. Consequently, reimbursement systems may need to be re-calibrated giving emphasis on price negotiation and value assessment based on local rules.

Recent trends in the region have included considerations relating to the adoption and implementation of HTA. Both Egypt (Ministry of Planning Monitoring and Administrative Reform (Egypt), 2016; ISPOR, 2019) and Kingdom of Saudi Arabia, 2020; Al-Omar et al., 2019) aspire to introduce such mechanisms while Lebanon and Morocco reportedly conduct token value assessments in some cases (Anonymous, 2018). As the use of health economics and other tools, including innovative contracting and RSAs, is very limited in MENA countries, the transition from a command-andcontrol system, such as ERP, to a value assessment system based on HTA principles, requires the fulfilment of certain prior actions, including: (a) a clear vision and roadmap for the incorporation of HTA in decision-making; (b) investment in human and physical infrastructure and data systems to support implementation; (c) building the relevant institution(s), deciding where HTA fits into current health system structures and how it interacts with other policy measures; (d) a period of piloting and learning; and (d) the separation from the registration process for new pharmaceuticals. Ultimately, the implementation of HTA principles requires a gradual shift in policy-making mindset towards an environment which is more transparent, collaborative, consultative, and is supportive of innovation and investment.

\section{Conclusions}

Having proposed an analytical framework to examine salient features of ERP systems, we undertook an assessment of how well MENA country ERP systems adhered to international best practice principles. ERP was shown to be the dominant pricing method for in-patent as well as off-patent pharmaceuticals, but most ERP systems present design flaws. Some of these can be rectified through incremental changes that require minimal intervention but have lasting impact on the overall ERP system, while others may require long-term, sustainable change in systems, institutions and mindsets. If implemented, changes can lead to fairer and sustainable pricing, a gradual shift towards value assessment conducted locally, greater equity in access to health technologies and innovation in the MENA region. While all MENA countries are looking to reform their health systems, there is still room for significant improvements in order to streamline fragmented sectors and improve access to care and population health outcomes.

\section{Declarations of Competing Interest}

This research is based on a project on pricing of prescription medicines in MENA countries, which was funded by a grant from the Pharmaceutical Research and Manufacturers of America (PhRMA). The sponsor was not involved in the study design, collection, analysis and interpretation of data, or writing of the report and publication of the study results.

\section{Acknowledgements}

We are grateful to the experts and stakeholders who provided insights and expertise on the topics of pricing and reimbursement in the Middle East and North Africa region through survey responses and telephone interviews. We are particularly thankful to Rania Ashraf, Gihan Hamdy El-Sisi, Sanae Mousannif, Yacine Sellam, and Mohammed Wadie Zerhouni. The paper has benefited from comments and suggestions by two anonymous referees to whom we are grateful. All outstanding errors are our own.

\section{References}

World Bank. World Bank DataBank: World Development Indicators. World Bank; 2019.

Kaló Z, Alabbadi I, Ghaleb Al Ahdab O, Alowayesh M, Elmahdawy M, Al-Saggabi AH Tanzi VL, Al-Badriyeh D, Alsultan HS, Hussain Ali FM, Elsisi GH, Akhras KS, Vokó and $\mathrm{K}$ Z. Implications of external price referencing of pharmaceuticals in Middle East countries. Expert Review of Pharmacoeconomics \& Outcomes Research 2015;15(6):993-8.

Qarain M, Tabbaa T, Goussous R. Assessment of the current pricing policy on the pharmaceutical sector. USAID 2009.

Business Monitor International (BMI). Egypt: Pharmaceuticals \& Healthcare Report Q1 2018. Industry Report \& Forecasts Series. London: BMI Research; 2017a.

Business Monitor International (BMI). Jordan: Pharmaceuticals \& Healthcare Report Q1 2018. Industry Report \& Forecasts Series. London: BMI Research; 2017b.

Business Monitor International (BMI). Algeria: Pharmaceuticals \& Healthcare Report Q1 2018. Industry Report \& Forecasts Series. London: BMI Research; 2017c.

Business Monitor International (BMI). Lebanon: Pharmaceuticals \& Healthcare Report Q1 2018. Industry Report \& Forecasts Series. London: BMI Research; 2017d.

Business Monitor International (BMI). Oman: Pharmaceuticals \& Healthcare Report Q1 2018. Industry Report \& Forecasts Series. London: BMI Research; 2017e.

Business Monitor International (BMI). Qatar: Pharmaceuticals \& Healthcare Report Q1 2018. Industry Report \& Forecasts Series. London: BMI Research; 2017f 
Business Monitor International (BMI). Middle East \& Africa Pharma \& Healthcare. Insight. London: BMI Research; $2017 \mathrm{~g}$.

World Health Organization. WHO Guideline On Country Pharmaceutical Pricing Policies. Geneva, Switzerland: WHO Document Production Services; 2015.

Espin J, Rovira J, Olry de Labry A. Working Paper 1: External Reference Pricing. WHO/HAI Project on Medicine Prices and Availability. World Health Organization, HAI Global; 2011.

Gill J, Fontrier A-M, Kyriopoulos D, Kanavos P. Variations in external reference pricing implementation: does it matter for public policy? The European Journal of Health Economics 2019;20(9):1375-97.

Kanavos P, Nicod E, Espin J, van den Aardweg S. Short-and long-term effects of valuebased pricing vs. external price referencing. EMiNET 2010.

Leopold C, Mantel-Teeuwisse AK, Seyfang L, Vogler S, de Joncheere K, Ogilvie Laing $\mathrm{R}$, et al. Impact of external price referencing on medicine prices - a price comparison among 14 European countries. Southern Med Review 2012;5(2):34-41.

Fontrier A-M, Gill J, Kanavos P. International impact of external reference pricing: should national policy-makers care? The European Journal of Health Economics 2019;20(8):1147-64

Kanavos P, Fontrier A-M, Gill J, Efthymiadou O. Does external reference pricing deliver what it promises? Evidence on its impact at national level. The European Journal of Health Economics 2020;21(1):129-51.

Håkonsen H, Horn A, Toverud E-L. Price control as a strategy for pharmaceutical cost containment-What has been achieved in Norway in the period 1994-2004? Health Policy 2009;90(2):277-85.

Sullivan SD, Kanavos P, Kalo Z. Principles for External Price Referencing of Medicines. London School of Economics; 2018.

Center for Reviews and Dissemination. Systematic Reviews: CRD's guidance for undertaking reviews in health care. York, UK: York Publishing Services: CRD, University of York; 2008.

Abuelkhair M, Abdu S, Godman B, Fahmy S, Malmström RE, Gustafsson LL. Imperative to consider multiple initiatives to maximize prescribing efficiency from generic availability: case history from Abu Dhabi. Expert Review of Pharmacoeconomics \& Outcomes Research 2012;12(1):115-24.

Hammad EA. The Use of Economic Evidence to Inform Drug Pricing Decisions in Jordan. Value in Health 2016;19(2):233-8.

Khan T, Emeka P, Suleiman A, Alnutafy F, Aljadhey H. Pharmaceutical Pricing Policies and Procedures in Saudi Arabia: A Narrative Review. Therapeutic Innovation \& Regulatory Science 2015;50(2):236-40.

Mohamed OE. The Impact of Direct Price Controls on Pharmaceutical Prices in Egypt. Ann Arbor: University of Wisconsin - Madison; 2014

Ministry of Health of the Sultanate of Oman and World Health Organization. Oman Pharmaceutical Country Profile. World Health Organization; 2011.

Business Monitor International (BMI). Saudi Arabia: Pharmaceuticals \& Healthcare Report Q1 2018. Industry Report \& Forecasts Series. London: BMI Research; 2017h.

Alrasheedy A, Hassali MA, Wong ZY, Aljadhey H, AL-Tamimi SK, Saleem F. Pharmaceutical policy in Saudi Arabia. In: Babar Zaheer-Ud-Din, editor. Pharmaceutical Policy in Countries with Developing Healthcare Systems. ADIS; 2017. p. 329-48.

Business Monitor International (BMI). Morocco: Pharmaceuticals \& Healthcare Report Q1 2017. Industry Report \& Forecasts Series. London: BMI Research; $2017 \mathrm{i}$.
Al Abbasi R, Al Jalahma M. Pricing Guideline: Kingdom of Bahrain. Kingdom of Bahrain: National Health Regulatory Authority (NHRA); 2017.

Anonymous. Interviewee, Interviews conducted with experts from Algeria, Bahrain, Egypt, Jordan, Kuwait, Morocco, Lebanon, Oman, Qatar, Saudi Arabia, and the UAE, LSE Interviewers: P. Kanavos and V. Tzouma [Interview]. London School of Economics; 2018].

Holtorf A, Gialama F, Wijaya K, Kaló Z. External Reference Pricing for Pharmaceuticals-A Survey and Literature Review to Describe Best Practices for Countries With Expanding Healthcare Coverage. In: Value in Health Regional Issues, no.19; 2019. p. 122-31.

Wanis H. Pharmaceutical pricing in Egypt. In: Babar Zaheer-Ud-Din, editor. Pharmaceutical Prices in the 21st Century. ADIS; 2015. p. 59-78.

El-Dahiyat F, Curley LE. Pharmaceutical policy in Jordan. In: Zaheer-Ud-Din Babar, editor. Pharmaceutical Policy in Countries with Developing Healthcare Systems. ADIS; 2017. p. 237-60.

Kanavos P, Saleh S, Kamphuis B, El Arnaout N, McClain K. Mapping of the Regulatory Environments in the Pharmaceutical Sector in SEMED. London: London School of Economics; 2018.

Abdel Rida N, Mohamed Ibrahim M, Babar Z. Relationship between pharmaceutical pricing strategies with price, availability, and affordability of cardiovascular disease medicines: surveys in Qatar and Lebanon. BMC Health Services Research 2019;19(973).

Ammar W. Chapter 4: Pharmaceuticals. In: Health Beyond Politics, World Health Organization Eastern Mediterranean Regional Office. Ministry of Public Health Lebanon; 2009.

Hajed $\mathrm{H}$ [Online]. Available: https://old.sfda.gov.sa/ar/news/Documents/ SaudiPricingGuidelinesandTheProposedNewSystem.pdf. [Accessed 23 July 2020] Saudi Pricing Guidelines and The Proposed New Pricing System; 2020.

United Arab Emirates Ministry of Health \& Prevention. Pricing Guidelines. D.D. Public Health Policy \& Licensing Sector; 2018

Business Monitor International (BMI). UAE: Pharmaceuticals \& Healthcare Report Q1 2018. Industry Report \& Forecasts Series. London: BMI Research; 2017j.

Ministry of Planning Monitoring and Administrative Reform (Egypt). Sustainable Development Strategy: Egypt's Vision 2030; 2016 [Online]. Available: https://www.greengrowthknowledge.org/sites/default/files/downloads policy-database/Egypt\%20Vision\%202030\%20\%28English\%29.pdf. [Accessed 23 July 2020].

Kingdom of Saudi Arabia [Online]. Available: https://vision2030.gov.sa/en. [Accessed 23 July 2020] Saudi Arabia Vision 2030; 2020.

ISPOR. Egypt - Pharmaceutical Global Health Technology Assessment Road Map; 2019 [Online]. Available: https://tools.ispor.org/htaroadmaps/EgyptPH. asp. [Accessed 22 October 2019].

Al-Omar H, Attuwaijri A, Aljuffali I. What local experts expect from a health technology assessment (HTA) entity in Saudi Arabia: workshop conclusions. Expert Review of Pharmacoeconomics \& Outcomes Research 2019:1-6.

Business Monitor International (BMI). Kuwait: Pharmaceuticals \& Healthcare Report Q1 2018. Industry Report \& Forecasts Series. London: BMI Research; 2017k.

Business Monitor International (BMI). Bahrain: Pharmaceuticals \& Healthcare Report Q1 2018. Industry Report \& Forecasts Series. London: BMI Research; 20171. 